\title{
Subclinical Thyroid Dysfunction and Depressive Symptoms among the Elderly: A Prospective Cohort Study
}

\author{
Manuel R. Blum ${ }^{a}$ Liselotte W. Wijsman ${ }^{b, f}$ Vanessa S. Virgini $^{a}$ \\ Douglas C. Bauer ${ }^{\mathrm{h}}$ Wendy P.J. den Elzen ${ }^{c, d} \quad$ J. Wouter Jukema ${ }^{\mathrm{e}}$ \\ Brendan M. Buckley ${ }^{i}$ Anton J.M. de Craen ${ }^{\mathrm{e}}$ Patricia M. Kearney ${ }^{j}$ David J. Stott ${ }^{k}$ \\ Jacobjin Gusseklooc Rudi G.J. Westendorp' Simon P. Mooijaart ${ }^{\text {b, f, g }}$ \\ Nicolas Rodondia on behalf of the PROSPER study group \\ ${ }^{a}$ Department of General Internal Medicine, Inselspital, Bern University Hospital, Bern, Switzerland; \\ Departments of ${ }^{\mathrm{b}}$ Gerontology and Geriatrics, ${ }^{\mathrm{c}}$ Public Health and Primary Care, ${ }^{\mathrm{d}}$ Clinical Chemistry and Laboratory

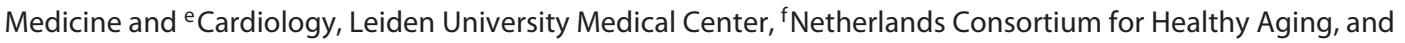 \\ ${ }^{g}$ Institute for Evidence-Based Medicine in Old Age, Leiden, The Netherlands; ${ }^{\text {h}}$ Department of Internal Medicine, \\ San Francisco University Center, San Francisco, Calif., USA; Departments of 'Pharmacology and Therapeutics \\ and ${ }^{\mathrm{j}}$ Epidemiology and Public Health, University College Cork, Cork, Ireland; ${ }^{\mathrm{k}}$ Institute of Cardiovascular and \\ Medical Sciences, University of Glasgow, Glasgow, UK; 'Department of Public Health, University of Copenhagen, \\ Copenhagen, Denmark
}

\section{Key Words}

Subclinical dysfunction - Thyroid - Depression - PROSPER study · Elderly subjects $\cdot$ Longitudinal design

\begin{abstract}
Background: Subclinical hypothyroidism has been associated with depressive symptoms in cross-sectional studies, but prospective data and data on subclinical hyperthyroidism are scarce. Methods: In the Leiden substudy of the Prospective Study of Pravastatin in the Elderly at Risk (PROSPER), thyroid-stimulating hormone and free $\mathrm{T}_{4}$ levels were measured at baseline and repeated after 6 months in adults aged 70-82 years with preexisting cardiovascular disease or known cardiovascular risk factors to define persistent thyroid functional status. Main outcome measures were depressive symptoms, assessed with the Geriatric Depression Scale
\end{abstract}

(c) 2015 S. Karger AG, Basel

0028-3835/15/0000-0000\$39.50/0
15 (GDS-15) at baseline and after 3 years. All analyses were adjusted for age, gender and education. Results: In 606 participants ( $41 \%$ women; mean age 75 years) without antidepressant medication, GDS-15 scores at baseline did not differ for participants with subclinical hypothyroidism ( $n=47$; GDS-15 score $1.75,95 \% \mathrm{Cl} 1.29-2.20, \mathrm{p}=0.53$ ) or subclinical hyperthyroidism ( $\mathrm{n}=13$; GDS-15 score $1.64,95 \% \mathrm{Cl} 0.78-$ $2.51, p=0.96)$ compared to euthyroid participants $(n=546$; mean GDS-15 score 1.60, 95\% Cl 1.46-1.73). After 3 years, compared to the euthyroid participants, changes in GDS-15 scores did not differ for participants with subclinical hypothyroidism ( $\triangle$ GDS- 15 score $-0.03,95 \% \mathrm{Cl}-0.50$ to $0.44, p=$ $0.83)$, while subclinical hyperthyroidism was associated with an increase in GDS scores ( $\triangle$ GDS-15 score $1.13,95 \% \mathrm{Cl} 0.32$

M.R. Blum and L.W. Wijsman contributed equally to this paper.

\section{KARGER 125}

E-Mail karger@karger.com www.karger.com/nen 
$1.93, p=0.04)$. All results were similar for persistent subclinical thyroid dysfunction. Conclusions: In this largest prospective study on the association of persistent subclinical thyroid dysfunction and depression, subclinical hypothyroidism was not associated with increased depressive symptoms among older adults at high cardiovascular risk. Persistent subclinical hyperthyroidism might be associated with increased depressive symptoms, which requires confirmation in a larger prospective study.

(c) 2015 S. Karger AG, Basel

\section{Introduction}

Subclinical thyroid dysfunction is biochemically defined as abnormal thyroid-stimulating hormone (TSH) levels with normal free $\mathrm{T}_{4}\left(\mathrm{fT}_{4}\right)$ levels. Subclinical hypothyroidism is characterized by elevated TSH levels, and subclinical hyperthyroidism by depressed TSH levels. Subclinical thyroid dysfunction is a common condition, especially among the elderly, with a prevalence reaching up to $18 \%$ for subclinical hypothyroidism [1-3] and up to $4 \%$ for subclinical hyperthyroidism [4].

Subclinical thyroid dysfunction has been associated with neuropsychiatric problems such as cognitive dysfunction and depressive symptoms [4]. Thyroid hormones are well known to exert effects on metabolic activity in the adult brain [5], and the American Psychiatric Association guidelines suggest thyroid function measurements in the evaluation of depressive symptoms [6]. In addition, thyroid hormone supplementation may increase the effectiveness of antidepressants in treatment of depression $[7,8]$. Some cross-sectional studies found an association with depressive symptoms for both subclinical hypothyroidism $[9,10]$ and subclinical hyperthyroidism [11]. Moreover, autoimmune thyroiditis, the most common cause of subclinical hypothyroidism among the elderly, has been shown to be more frequent in depressed patients than in healthy euthyroid individuals (20 vs. $5 \%$ ) [12]. However, only few studies have prospectively compared euthyroidism with subclinical thyroid dysfunction and depression: two prospective studies found no association between subclinical hypothyroidism and depressive symptoms, but one of these included only the very elderly, all being aged 85 years and older [13], and another included only elderly men aged 70 years and older [14].

Therefore, we assessed the association between subclinical thyroid dysfunction and the development of depressive symptoms in a post hoc substudy of the Prospec- tive Study of Pravastatin in the Elderly at Risk (PROSPER) [15]. In 606 men and women, we investigated the association of thyroid status at baseline and persistent thyroid status after 6 months with depressive symptoms during a mean follow-up period of 3.2 years.

\section{Subjects and Methods}

\section{Study Population}

We analyzed the participants in a substudy [16] of the PROSPER trial, a large international double-blinded randomized placebo-controlled clinical trial assessing the effect of pravastatin on the risk of cardiovascular and cerebrovascular events in elderly participants during a mean follow-up period of 3 years. The design of the PROSPER study $[15,17]$ has been described elsewhere. In summary, 5,804 men and women aged 70-82 years with preexisting cardiovascular or cerebrovascular disease or at high risk of developing such a disease were included in the PROSPER study. Participants with Mini-Mental State Examination (MMSE) scores $<24$ were excluded. Neither the current presence nor a history of depression were specified as inclusion or exclusion criteria in the PROSPER study. Out of 1,100 eligible Dutch participants, 650 subjects consented to participate in the nested MRI substudy of the PROSPER cohort [16] and had both thyroid function and depressive symptoms evaluated, the latter by the Geriatric Depression Scale 15 (GDS-15).

\section{Thyroid Function}

Details on the measurement of TSH and $\mathrm{fT}_{4}$ levels within the PROSPER study have been described elsewhere [18]. TSH and $\mathrm{fT}_{4}$ levels were measured at baseline and after 6 months using thirdgeneration immunoassays. The participants were categorized according to TSH levels at baseline and at follow-up. Based on the recent literature and current guidelines, subclinical hyperthyroidism was defined as TSH levels $<0.45 \mathrm{mIU} / \mathrm{l}$, and subclinical hypothyroidism was defined as TSH levels $\geq 4.5 \mathrm{mIU} / \mathrm{l}$, with $\mathrm{fT}_{4}$ within the reference range (12-18 pmol/l) [19-22]. Participants with TSH levels $\geq 0.45 \mathrm{mIU} / \mathrm{l}$ and $<4.5 \mathrm{mIU} / \mathrm{l}$ were considered euthyroid. Subgroups of subclinical hypothyroidism were defined as TSH levels $4.5-10$ and $>10 \mathrm{mIU} / \mathrm{l}$, while subgroups of subclinical hyperthyroidism were defined as TSH levels $0.1-0.44$ and $<0.1$ $\mathrm{mIU} / \mathrm{l}[2,23]$. As subclinical thyroid dysfunction may spontaneously revert to normal thyroid function over time [24-26], we used a follow-up measurement of thyroid function after 6 months to define participants with persistent subclinical thyroid dysfunction or persistent euthyroidism from baseline until 6 months of follow-up [27].

\section{Depressive Symptoms}

Depressive symptoms were assessed at baseline and after 3.2 years of follow-up using the GDS-15 [28], a tool developed specifically for elderly patients and validated for outpatient use [29, 30]. The GDS-15 consists of 15 'yes/no' questions on functional and depressive mood symptoms, resulting in total scores ranging from 0 to 15 , with higher scores indicative of more depressive symptoms. A recent systematic review on the accuracy of different screening instruments for depression in older hospitalized patients 


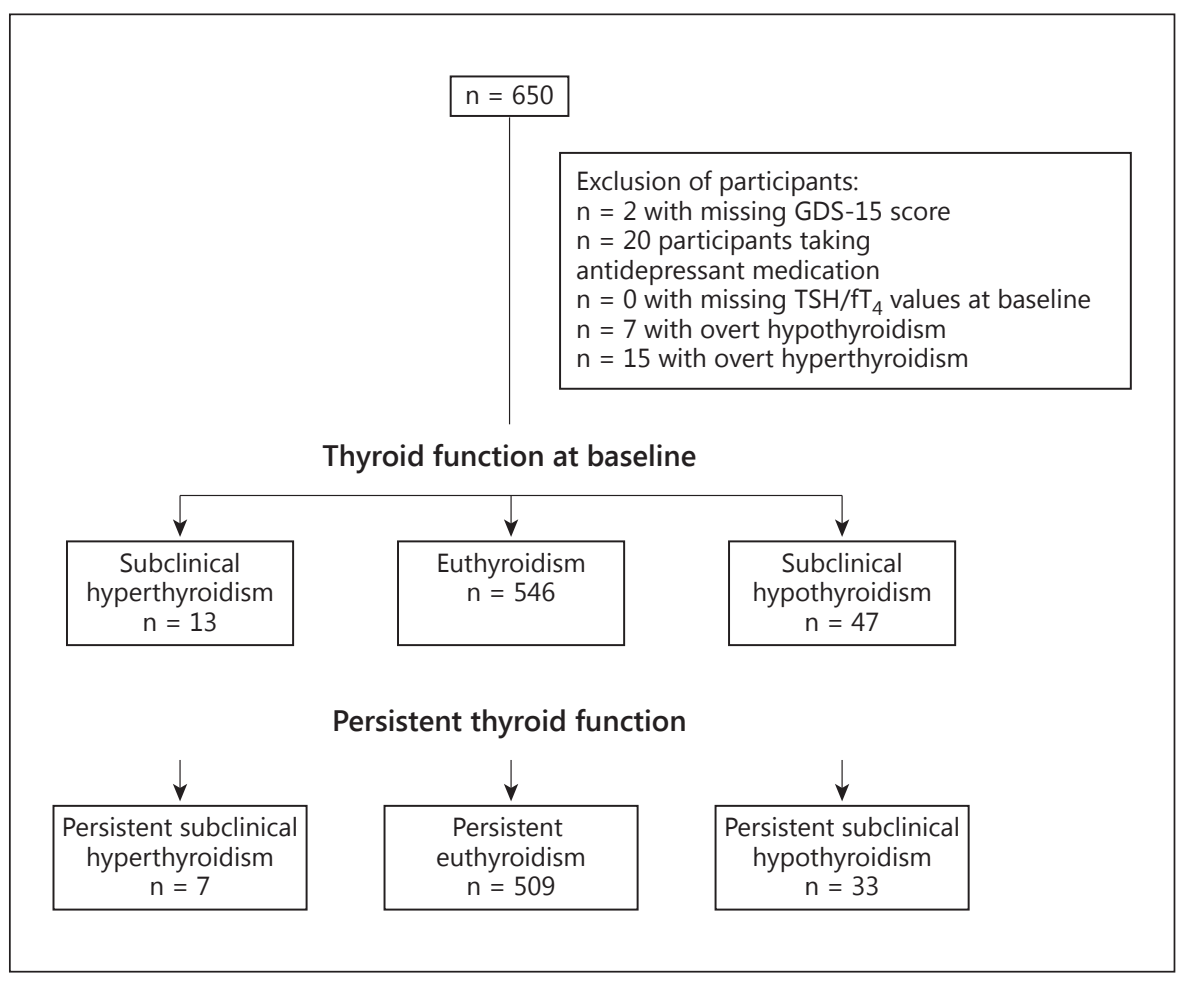

Fig. 1. Flowchart of the study participants.

found the GDS-15 to be the most validated test [31]. It has been shown that it is a valid tool for measuring longitudinal changes in depressive symptoms [32]. Based on the existing literature, a difference in GDS- 15 scores of $0.5-2$ points was considered clinically meaningful $[32,33]$. The use of antidepressant medication was assessed at baseline.

\section{Statistical Analysis}

Baseline characteristics were grouped according to thyroid status (euthyroid, subclinical hypothyroidism and subclinical hyperthyroidism). Baseline characteristics of the groups with subclinical thyroid dysfunction were compared to those of the euthyroid group using two-sample t tests and $\chi^{2}$ tests. Linear regression analyses were performed to assess the cross-sectional association between subclinical thyroid status and depressive symptoms, adjusting for age, gender and education (minimally adjusted model). In a multivariable adjusted model, we additionally adjusted for vascular risk factors (defined as history of vascular disease, history of hypertension, history of diabetes mellitus, current smoking, and treatment with pravastatin or placebo).

We also performed stratified analyses in which we investigated the subgroups of subclinical hypothyroidism and subclinical hyperthyroidism. Furthermore, we performed sensitivity analyses in which we (1) excluded participants on thyroxin or antithyroid medication at baseline, (2) included participants on antidepressant medications at baseline and (3) excluded participants taking up antidepressant medication during follow-up. Two-sided $\mathrm{p}$ values $<0.05$ were considered statistically significant. All analyses were conducted using SPSS (version 20.0; PASW Statistics Inc., Chicago, Ill., USA).

Subclinical Thyroid Dysfunction and Depressive Symptoms

\section{Results}

For the present analysis, we excluded 22 participants with overt thyroid dysfunction, 2 participants with missing GDS-15 scores at baseline and 20 participants on antidepressant medication at baseline, yielding a final study sample of 606 participants (fig. 1).

\section{Baseline Characteristics}

The baseline characteristics are shown in table 1. Of all participants, $41.3 \%$ were female. The mean age of the study population was 75 years. A total of 13 participants (2.2\%) had subclinical hyperthyroidism and 47 participants $(7.8 \%)$ had subclinical hypothyroidism. Baseline characteristics did not differ between the subclinical thyroid dysfunction groups and the euthyroid group, except for the lower educational status, higher use of thyroxine medication, higher share of female participants and lower body height of the participants with subclinical hypothyroidism, and the lower diastolic blood pressure in participants with subclinical hyperthyroidism.

\section{Baseline Thyroid Status and Depressive Symptoms}

Table 2 shows the association of baseline thyroid status with GDS-15 score at baseline and change in GDS-15 
Table 1. Baseline characteristics of study participants by subclinical thyroid status

\begin{tabular}{|c|c|c|c|c|c|c|}
\hline & $\begin{array}{l}\text { All } \\
(n=606)\end{array}$ & \multicolumn{3}{|c|}{ Subclinical thyroid status } & \multicolumn{2}{|c|}{$\mathrm{p}$ value for difference } \\
\hline TSH level, mIU/l & $2.38 \pm 2.31$ & $0.18 \pm 0.15$ & $1.97 \pm 0.90$ & $7.72 \pm 5.29$ & & \\
\hline $\mathrm{fT}_{4}, \mathrm{pmol} / \mathrm{l}$ & $16.46 \pm 2.14$ & $15.98 \pm 1.37$ & $16.62 \pm 2.14$ & $14.83 \pm 1.57$ & & \\
\hline Age, years & $75.02 \pm 3.21$ & $75.17 \pm 3.00$ & $74.96 \pm 3.20$ & $75.66 \pm 3.40$ & 0.82 & 0.16 \\
\hline Age left school, years & $15.45 \pm 2.91$ & $15.77 \pm 3.44$ & $15.52 \pm 2.94$ & $14.49 \pm 2.24$ & 0.77 & 0.01 \\
\hline GDS- 15 score $>4$ & $56(9.2)$ & $1(7.7)$ & $7(14.9)$ & $48(8.8)$ & 0.89 & 0.17 \\
\hline \multicolumn{7}{|l|}{ Biometrics } \\
\hline Weight, kg & $77.33 \pm 11.93$ & $71.73 \pm 11.00$ & $77.70 \pm 12.08$ & $74.60 \pm 9.67$ & 0.08 & 0.09 \\
\hline \multicolumn{7}{|l|}{ Risk factors } \\
\hline Current smoker & $131(21.6)$ & $1(7.7)$ & $123(22.5)$ & $7(14.9)$ & 0.20 & 0.23 \\
\hline Excessive alcohol use $\mathrm{a}^{\mathrm{a}}$ & $60(9.9)$ & $0(0.0)$ & $57(10.4)$ & $3(6.4)$ & 0.22 & 0.38 \\
\hline History of diabetes & $107(17.7)$ & $5(38.5)$ & $96(17.6)$ & $6(12.8)$ & 0.05 & 0.40 \\
\hline History of hypertension & $377(62.2)$ & $8(61.5)$ & $337(61.7)$ & $32(68.1)$ & 0.99 & 0.39 \\
\hline History of vascular disease & $273(45.0)$ & $6(46.2)$ & $241(44.1)$ & $21(55.3)$ & 0.89 & 0.14 \\
\hline History of TIA/stroke & $98(16.2)$ & $2(15.4)$ & $87(15.9)$ & $9(19.1)$ & 0.96 & 0.57 \\
\hline Use of thyroxin & $15(2.5)$ & $0(0.0)$ & $8(1.5)$ & 7 (14.9) & 0.66 & $<0.001$ \\
\hline
\end{tabular}

Data represent means \pm SD or $\mathrm{n}(\%) . \mathrm{BMI}=$ Body mass index; $\mathrm{SBP}=$ systolic blood pressure; $\mathrm{DBP}=$ diastolic blood pressure; $\mathrm{TIA}=$ transient ischemic attack. ${ }^{a}$ Defined as $>21$ units per week for males and $>14$ units per week for females.

Table 2. Association of baseline subclinical thyroid status with GDS-15 score

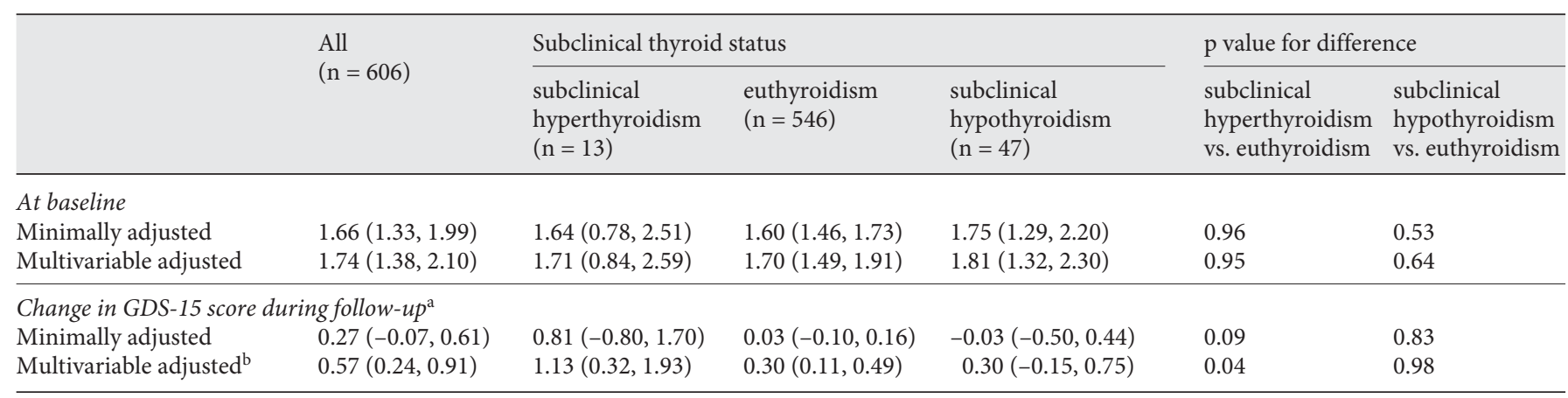

Data represent means (95\% CI). Higher scores mean more depressive symptoms. Minimally adjusted: adjusted for age, sex and education. Multivariable adjusted: additionally adjusted for history of vascular disease, history of hypertension, history of diabetes mellitus, current smoking and treatment with

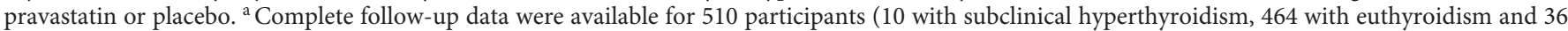
with subclinical hypothyroidism). ${ }^{\mathrm{b}}$ Additionally adjusted for baseline GDS-15 score. 
Table 3. Association of persistent subclinical thyroid status with GDS-15 score

\begin{tabular}{|c|c|c|c|c|c|c|}
\hline & \multirow{2}{*}{$\begin{array}{l}\text { All } \\
(\mathrm{n}=549)\end{array}$} & \multicolumn{3}{|c|}{ Subclinical thyroid status } & \multicolumn{2}{|c|}{$\mathrm{p}$ value for difference } \\
\hline & & $\begin{array}{l}\text { subclinical } \\
\text { hyperthyroidism } \\
(\mathrm{n}=7)\end{array}$ & $\begin{array}{l}\text { euthyroidism } \\
(\mathrm{n}=509)\end{array}$ & $\begin{array}{l}\text { subclinical } \\
\text { hypothyroidism } \\
(\mathrm{n}=33)\end{array}$ & $\begin{array}{l}\text { subclinical } \\
\text { hyperthyroidism } \\
\text { vs. euthyroidism }\end{array}$ & $\begin{array}{l}\text { subclinical } \\
\text { hypothyroidism } \\
\text { vs. euthyroidism }\end{array}$ \\
\hline \multicolumn{7}{|l|}{ At baseline } \\
\hline Minimally adjusted & $1.70(1.27,2.14)$ & $1.86(0.69,3.02)$ & $1.57(1.43,1.71)$ & $1.68(1.14,2.22)$ & 0.66 & 0.70 \\
\hline Multivariable adjusted & $1.77(1.31,2.23)$ & $1.97(0.79,3.15)$ & $1.65(1.44,1.87)$ & $1.68(1.11,2.25)$ & 0.62 & 0.92 \\
\hline \multicolumn{7}{|c|}{ Change in GDS-15 score during follow-up $p^{\mathrm{a}}$} \\
\hline Minimally adjusted & $0.40(0.00,0.80)$ & $1.00(-0.07,2.07)$ & $0.02(-0.11,0.16)$ & $0.17(-0.37,0.71)$ & 0.07 & 0.59 \\
\hline Multivariable adjusted ${ }^{\mathrm{b}}$ & $0.79(0.41,1.18)$ & $1.53(0.58,2.49)$ & $0.28(0.09,0.47)$ & $0.56(0.06,1.06)$ & 0.01 & 0.26 \\
\hline \multicolumn{7}{|c|}{ 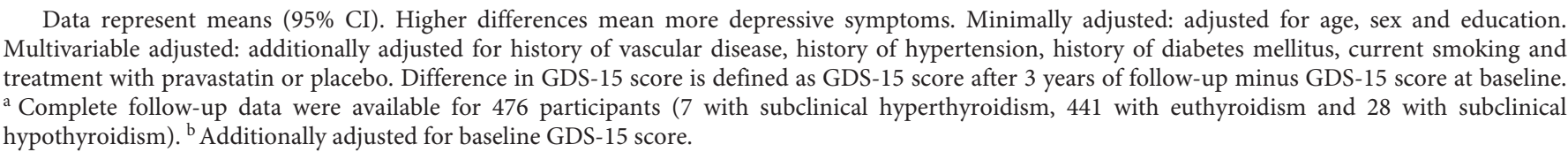 } \\
\hline
\end{tabular}

score during follow-up. At baseline, there was no significant difference in mean GDS-15 scores between euthyroid participants and participants with subclinical hyperthyroidism or hypothyroidism. During follow-up, participants with subclinical hyperthyroidism showed a higher increase in GDS-15 score when compared to euthyroid participants, which only reached statistical significance in the multivariable adjusted model.

\section{Persistent Thyroid Status and Depressive Symptoms}

Table 3 shows the association of persistent thyroid status with GDS-15 score at baseline and change in GDS-15 score during follow-up. A total of 33 out of 47 participants (70.2\%) had subclinical hypothyroidism both at baseline and at 6 months of follow-up and were therefore defined as having persistent subclinical hypothyroidism. For subclinical hyperthyroidism, a total of 7 out of 13 participants $(53.8 \%)$ had this condition at baseline and at 6 months of follow-up and were defined as having persistent subclinical hyperthyroidism. There was no significant difference in mean GDS-15 score at baseline between persistent euthyroid participants and participants with persistent subclinical hyperthyroidism or hypothyroidism. During followup, the minimally adjusted model showed that participants with persistent subclinical hyperthyroidism had a nonsignificant increase in GDS-15 score when compared to persistent euthyroid participants. In the multivariable adjusted model, this difference reached statistical significance.

\section{Stratified and Sensitivity Analyses}

Stratification of TSH levels showed that subclinical hyperthyroidism participants with very low TSH levels
$(<0.1 \mathrm{mIU} / \mathrm{l})$ at baseline had a significant increase in GDS-15 score after 3 years of follow-up when compared to euthyroid participants (difference in GDS-15 score: $1.50,95 \%$ CI $0.10-2.90, \mathrm{p}=0.04$; table 4 ); however, this subgroup included only a small sample of 5 participants. Analyses excluding participants on thyroid hormone replacement $(\mathrm{n}=15)$ and on antithyroid medication $(\mathrm{n}=2)$ did not change our results (online suppl. table 1; see www.karger.com/doi/10.1159/000437387 for all online suppl. material). The inclusion of 20 participants on antidepressant medication at baseline to the analyses did not materially change results either (online suppl. table 2). Analyses excluding participants using antidepressant medication during follow-up (overall: $\mathrm{n}=41 ; 6.8 \%$; 2 with subclinical hyperthyroidism, 2 with subclinical hypothyroidism) yielded similar results (online suppl. table 3). A low number of participants developed an MMSE score $<24$ during follow-up $(\mathrm{n}=20$; 1 with subclinical hyperthyroidism, none with subclinical hypothyroidism).

\section{Discussion}

In this large prospective cohort study of 606 older adults, we found that both baseline and persistent subclinical hypothyroidism were not associated with increased depressive symptoms as assessed by the GDS- 15 . Conversely, results were consistent with a possible association between subclinical hyperthyroidism and increased depressive symptoms. To our knowledge, this study is currently the largest prospective study on the as- 
Table 4. Association of baseline subclinical thyroid status with GDS-15 score, stratified for very low and very high TSH values

\begin{tabular}{|c|c|c|c|c|c|c|c|c|c|c|}
\hline & \multirow{2}{*}{$\begin{array}{l}\text { All } \\
(\mathrm{n}=606)\end{array}$} & \multicolumn{2}{|c|}{ Subclinical hyperthyroidism } & \multirow{2}{*}{$\begin{array}{l}\text { Euthyroidism } \\
\text { (TSH } \\
0.45-4.49 \mathrm{mIU} / \mathrm{l} ; \\
\mathrm{n}=546)\end{array}$} & \multicolumn{2}{|c|}{ Subclinical hypothyroidism } & \multicolumn{4}{|c|}{$\mathrm{p}$ value for difference } \\
\hline & & $\begin{array}{l}\text { TSH } \\
<0.1 \mathrm{mIU} / 1 \\
(\mathrm{n}=5)\end{array}$ & $\begin{array}{l}\text { TSH } \\
0.1-0.45 \mathrm{mIU} / \mathrm{l} \\
(\mathrm{n}=8)\end{array}$ & & $\begin{array}{l}\text { TSH } \\
4.50-10 \mathrm{mIU} / \mathrm{l} \\
(\mathrm{n}=41)\end{array}$ & $\begin{array}{l}\text { TSH } \\
>10 \mathrm{mIU} / \mathrm{l} \\
(\mathrm{n}=6)\end{array}$ & $\begin{array}{l}\text { TSH } \\
<0.1 \mathrm{mIU} / 1 \\
\text { vs. euthyr. }\end{array}$ & $\begin{array}{l}\text { TSH } \\
0.1-0.45 \mathrm{mIU} / \mathrm{l} \\
\text { vs. euthyr. }\end{array}$ & $\begin{array}{l}\text { TSH } \\
4.50-10 \mathrm{mIU} / \mathrm{l} \\
\text { vs. euthyr. }\end{array}$ & $\begin{array}{l}\text { TSH } \\
>10 \text { mIU/l } \\
\text { vs. euthyr. }\end{array}$ \\
\hline \multicolumn{11}{|l|}{ At baseline } \\
\hline Minimally adjusted & $\begin{array}{l}1.75 \\
(1.30,2.20)\end{array}$ & $\begin{array}{l}1.89 \\
(0.50,3.29)\end{array}$ & $\begin{array}{l}1.49 \\
(0.38,2.59)\end{array}$ & $\begin{array}{l}1.60 \\
(1.46,1.73)\end{array}$ & $\begin{array}{l}1.70 \\
(1.21,2.19)\end{array}$ & $\begin{array}{l}2.08 \\
(0.81,3.36)\end{array}$ & 0.67 & 0.79 & 0.69 & 0.47 \\
\hline Multivariable adjusted & $\begin{array}{l}1.84 \\
(1.36,2.31)\end{array}$ & $\begin{array}{l}2.02 \\
(0.61,3.42)\end{array}$ & $\begin{array}{l}1.52 \\
(0.40,2.64)\end{array}$ & $\begin{array}{l}1.70 \\
(1.49,1.91)\end{array}$ & $\begin{array}{l}1.75 \\
(1.23,2.27)\end{array}$ & $\begin{array}{l}2.20 \\
(0.91,3.49)\end{array}$ & 0.65 & 0.66 & 0.83 & 0.45 \\
\hline \multicolumn{11}{|c|}{ Change in GDS-15 score during follow-up ${ }^{\mathrm{a}}$} \\
\hline Minimally adjusted & $\begin{array}{l}0.19 \\
(-0.28,0.66)\end{array}$ & $\begin{array}{l}1.50 \\
(0.10,2.90)\end{array}$ & $\begin{array}{l}0.34 \\
(-0.80,1.49)\end{array}$ & $\begin{array}{l}0.03 \\
(-0.10,0.16)\end{array}$ & $\begin{array}{l}0.10 \\
(-0.40,0.60)\end{array}$ & $\begin{array}{l}-1.04 \\
(-2.44,0.36)\end{array}$ & 0.04 & 0.59 & 0.78 & 0.14 \\
\hline Multivariable adjusted $^{\mathrm{b}}$ & $\begin{array}{l}0.59 \\
(0.14,1.04)\end{array}$ & $\begin{array}{l}2.00 \\
(0.73,3.26)\end{array}$ & $\begin{array}{l}0.53 \\
(-0.51,1.58)\end{array}$ & $\begin{array}{l}0.29 \\
(0.10,0.48)\end{array}$ & $\begin{array}{l}0.35 \\
(-0.12,0.82)\end{array}$ & $\begin{array}{l}-0.21 \\
(-1.48,1.06)\end{array}$ & 0.01 & 0.66 & 0.80 & 0.45 \\
\hline
\end{tabular}

sociation of persistent subclinical thyroid dysfunction with depression.

The evidence on the association between subclinical hyperthyroidism and depressive symptoms in elderly people is scarce, and comparison is made difficult due to the use of diverse scales to assess depressive symptoms. One cross-sectional study $(\mathrm{n}=3,756)$ found that depression was more prevalent in women who had a low serum TSH level $(<0.4 \mathrm{mIU} / \mathrm{l})$ among patients admitted to three psychiatric hospitals [34]. However, in this cross-sectional study, low TSH concentrations could be the consequence rather than a cause of the psychiatric illness and hospitalization [4]. One Turkish nonrandomized interventional study of 160 participants (13 with subclinical hyperthyroidism) found an improvement in depressive symptoms as assessed by the Hamilton Depression Rating Scale 9.1 months after treatment of subclinical hyperthyroidism with propylthiouracil [35]. Conversely, in a small randomized controlled trial of 33 participants, depressive symptoms showed an improvement after induction of exogenous subclinical hyperthyroidism over a follow-up time of 12 weeks [36]. Other large cross-sectional analyses ( $\mathrm{n}=254-30,589)$ [37-39] found no association, and one population-based prospective study of 3,932 participants (31 with subclinical hyperthyroidism) [14] found no association of subclinical hyperthyroidism with depressive episodes classified according to the ICD-9, suggesting that previous positive studies and our finding of increased depressive symptoms particularly in participants with very low TSH levels are possibly due to chance. To better understand the possible pathophysiological mechanisms of this association, future studies should assess parameters of the hypothalamic-pituitary-adrenal axis, such as serum glucocorticoid levels, corticotropinreleasing hormone and adrenocorticotropic hormone (not measured in the present study), since a previous study found that adults with depression had higher cortisol levels compared to control subjects without psychiatric disorders [40].

Subclinical hypothyroidism has previously been associated with depressive symptoms in smaller cross-sectional studies $(\mathrm{n}=323-583)[9,10]$. In a recent study of 323 participants over 60 years of age, subclinical hypothyroidism was identified as a risk factor for depressive symptoms (OR 4.9, 95\% CI 2.8-8.6) [9]. However, several large cross-sectional studies of elderly patients ( $\mathrm{n}=$ $3,932-30,589$ ) found no association $[14,39,41]$. This is in line with a prospective observational study of $558 \mathrm{pa}-$ tients aged over 85 years $(\mathrm{n}=30$ with subclinical hypothyroidism defined by TSH $>4.8 \mathrm{mIU} / \mathrm{l}$ and normal $\mathrm{fT}_{4}$ ), which showed that over a mean follow-up time of 3.7 years TSH and $\mathrm{fT}_{4}$ levels were not associated with depressive symptoms as assessed by the GDS-15 [13]. In an Australian population-based prospective study of 3,932 men aged 70 years and older ( 31 with subclinical hyperthyroidism), baseline subclinical hypothyroidism was not associated with depression either cross-sectionally or prospectively. However, this study did not follow depression outcomes systematically in all participants, as incident depression disorders were assessed by collecting ICD-9-coded diagnoses through data linkage [14]. The comparability of these findings is, however, limited, since current evidence suffers from the multitude of questionnaires, assessments and cutoffs used for the def- 
inition of depression. Also, studies differ in the selection and characteristics of patients, such as age range and gender. For example, in the abovementioned positive crosssectional study [9], participants were derived from internal medicine and psychiatry outpatient clinics and may have had more pronounced depressive symptoms than population-based study samples from some negative cross-sectional studies $[14,39]$. In addition, a small randomized clinical trial assessing the effects of levothyroxine replacement therapy versus placebo for 6 months in 40 women with subclinical hypothyroidism (mean age 49 years) found no significant change in the Hospital Anxiety and Depression Scale score in the intervention group, suggesting that thyroxine replacement therapy does not improve depression in women [42]. Our findings from a large prospective cohort add to the evidence that subclinical hypothyroidism is not associated with depression, at least in older adults.

The present study has several limitations. The number of participants with subclinical hypothyroidism and particularly subclinical hyperthyroidism is relatively small, but to our knowledge, this is the largest prospective study assessing depressive symptoms associated with persistent subclinical hypothyroidism and subclinical hyperthyroidism in older men and women. The study population for this analysis was derived from a randomized controlled trial of older patients at high cardiovascular risk or existing cardiovascular disease, which might limit the generalizability of our findings. On the other hand, both subclinical thyroid dysfunction and depression are prevalent in older age, which should increase the power to detect an association. In the present study, the GDS-15 scores were generally relatively low, with only $5.2 \%$ of the participants having an elevated GDS-15 score (defined as $>4$ ) at baseline. Therefore, our data might not be generalizable to patients with severe depression. The uptake of antidepressant medication during follow-up potentially influences results; however, the number of the participants requiring antidepressant medication was low, and a sensitivity analysis excluding these did not change results. We defined thyroid dysfunction by abnormal TSH and normal $\mathrm{fT}_{4}$ levels, as has been done in other large population-based studies on the risks associated with thyroid dysfunction [43-46]. Further parameters for assessing thyroid function, such as $\mathrm{T}_{3}$ levels, antithyroglobulin levels or thyroid ultrasound, were not available. Some participants with nonthyroidal illness may have been included in the study, although inclusion was limited to community-dwelling elderly individuals who could attend a clinical visit.

Subclinical Thyroid Dysfunction and Depressive Symptoms
The present study has several strengths. Most existing studies based their classification of participants on a single baseline measurement of TSH and $\mathrm{fT}_{4}$ only. However, subclinical hypothyroidism has been shown to resolve to normal TSH values without intervention over time [24$26]$, which we addressed by using thyroid function measurement after 6 months to define persistent subclinical thyroid dysfunction. We used a well-validated screening tool for depressive symptoms, which has been shown to be valid for the assessment of longitudinal changes as well [32]. In addition, given the gradual course of depression, our mean follow-up duration of 3 years should be well suited to assess long-term changes of depressive symptoms.

What are the clinical implications? According to current guidelines, treatment of subclinical hyperthyroidism should be strongly considered if TSH is persistently $<0.1$ $\mathrm{mIU} / \mathrm{l}$ for those aged 65 years and older, and treatment should also be considered for this age group if TSH is low but $\geq 0.1 \mathrm{mIU} / 1$. Our results, showing an association of persistent subclinical hyperthyroidism with increased depressive symptoms, are consistent with these recommendations. Although evidence from observational data should be used with caution in clinical decision-making, no randomized controlled trial examined the impact of treating subclinical hyperthyroidism on depressive symptoms.

In conclusion, we found some evidence of an association of persistent subclinical hyperthyroidism - but no evidence of an association of persistent subclinical hypothyroidism - with increased depressive symptoms, at least among well-functioning older adults. The association between persistent subclinical hyperthyroidism and increased depressive symptoms requires to be confirmed in a larger prospective study.

\section{Acknowledgements}

This research was supported by grants from the Swiss National Science Foundation (SNSF 320030-138267 and 320030-150025) and partially supported by a grant from the Swiss Heart Foundation (all to N. Rodondi). The original PROSPER study was supported by an unrestricted, investigator-initiated grant from Bristol-Myers Squibb.

\section{Disclosure Statement}

No competing financial interests exist. 


\section{References}

1 Jones DD, May KE, Geraci SA: Subclinical thyroid disease. Am J Med 2010;123:502-504.

2 Rodondi N, den Elzen WP, Bauer DC, Cappola AR, Razvi S, Walsh JP, Asvold BO, Iervasi $\mathrm{G}$, Imaizumi $\mathrm{M}$, Collet $\mathrm{TH}$, Bremner $\mathrm{A}$, Maisonneuve P, Sgarbi JA, Khaw KT, Vanderpump MP, Newman AB, Cornuz J, Franklyn JA, Westendorp RG, Vittinghoff E, Gussekloo J: Subclinical hypothyroidism and the risk of coronary heart disease and mortality. JAMA 2010;304:1365-1374.

3 Villar HC, Saconato H, Valente O, Atallah AN: Thyroid hormone replacement for subclinical hypothyroidism. Cochrane Database Syst Rev 2007;3:CD003419.

4 Biondi B, Cooper DS: The clinical significance of subclinical thyroid dysfunction. Endocr Rev 2008;29:76-131.

5 Bauer M, Goetz T, Glenn T, Whybrow PC: The thyroid-brain interaction in thyroid disorders and mood disorders. J Neuroendocrinol 2008;20:1101-1114.

6 Gelenberg AJ, Freeman MP, Markowitz JC, Rosenbaum JF, Thase ME, Trivedi MH, Van Rhoads RS: Practice guideline for the treatment of patients with major depressive disorder, ed 3. Suppl Am J Psychiatry 2010;167:1118.

7 Cooper-Kazaz R, Apter JT, Cohen R, Karagichev L, Muhammed-Moussa S, Grupper D, Drori T, Newman ME, Sackeim HA, Glaser B, Lerer B: Combined treatment with sertraline and liothyronine in major depression: a randomized, double-blind, placebocontrolled trial. Arch Gen Psychiatry 2007;64: 679-688.

8 Chang CM, Sato S, Han C: Evidence for the benefits of nonantipsychotic pharmacological augmentation in the treatment of depression. CNS Drugs 2013;27(suppl 1):S21-S27.

9 Chueire VB, Romaldini JH, Ward LS: Subclinical hypothyroidism increases the risk for depression in the elderly. Arch Gerontol Geriatr 2007;44:21-28.

10 Carta MG, Loviselli A, Hardoy MC, Massa S, Cadeddu M, Sardu C, Carpiniello B, Dell'Osso L, Mariotti S: The link between thyroid autoimmunity (antithyroid peroxidase autoantibodies) with anxiety and mood disorders in the community: a field of interest for public health in the future. BMC Psychiatry 2004;4:25.

11 Jaracz J, Kucharska A, Rajewska-Rager A, Lacka K: Cognitive functions and mood during chronic thyrotropin-suppressive therapy with L-thyroxine in patients with differentiated thyroid carcinoma. J Endocrinol Invest 2012;35:760-765.

12 Nemeroff CB, Simon JS, Haggerty JJ Jr, Evans DL: Antithyroid antibodies in depressed patients. Am J Psychiatry 1985;142:840-843.
13 Gussekloo J, van Exel E, de Craen AJ, Meinders AE, Frolich M, Westendorp RG: Thyroid status, disability and cognitive function, and survival in old age. JAMA 2004;292: 2591-2599.

14 Almeida OP, Alfonso H, Flicker L, Hankey G, Chubb SA, Yeap BB: Thyroid hormones and depression: the Health in Men Study. Am J Geriatr Psychiatry 2011;19:763-770.

15 Shepherd J, Blauw GJ, Murphy MB, Cobbe SM, Bollen EL, Buckley BM, Ford I, Jukema JW, Hyland M, Gaw A, Lagaay AM, Perry IJ, Macfarlane PW, Meinders AE, Sweeney BJ, Packard CJ, Westendorp RG, Twomey C, Stott DJ: The design of a Prospective Study of Pravastatin in the Elderly at Risk (PROSPER). PROSPER study group. Prospective Study of Pravastatin in the Elderly at Risk. Am J Cardiol 1999;84:1192-1197.

16 van den Heuvel DM, Admiraal-Behloul F, ten Dam VH, Olofsen H, Bollen EL, Murray HM, Blauw GJ, Westendorp RG, de Craen AJ, van Buchem MA: Different progression rates for deep white matter hyperintensities in elderly men and women. Neurology 2004;63:16991701 .

17 Shepherd J, Blauw GJ, Murphy MB, Bollen EL, Buckley BM, Cobbe SM, Ford I, Gaw A, Hyland M, Jukema JW, Kamper AM, Macfarlane PW, Meinders AE, Norrie J, Packard CJ, Perry IJ, Stott DJ, Sweeney BJ, Twomey C, Westendorp RG: Pravastatin in elderly individuals at risk of vascular disease (PROSPER): a randomised controlled trial. Lancet 2002; 360:1623-1630.

18 Nanchen D, Gussekloo J, Westendorp RG, Stott DJ, Jukema JW, Trompet S, Ford I, Welsh P, Sattar N, Macfarlane PW, Mooijaart SP, Rodondi N, de Craen AJ: Subclinical thyroid dysfunction and the risk of heart failure in older persons at high cardiovascular risk. J Clin Endocrinol Metab 2012;97:852-861.

19 Collet TH, Gussekloo J, Bauer DC, den Elzen WP, Cappola AR, Balmer P, Iervasi G, Asvold BO, Sgarbi JA, Völzke H, Gencer B, Maciel RM, Molinaro S, Bremner A, Luben RN, Maisonneuve P, Cornuz J, Newman AB, Khaw KT, Westendorp RG, Franklyn JA, Vittinghoff E, Walsh JP, Rodondi N: Subclinical hyperthyroidism and the risk of coronary heart disease and mortality. Arch Intern Med 2012; 172:799-809.

20 Gencer B, Collet TH, Virgini V, Bauer DC, Gussekloo J, Cappola AR, Nanchen D, den Elzen WP, Balmer P, Luben RN, Iacoviello M, Triggiani V, Cornuz J, Newman AB, Khaw KT, Jukema JW, Westendorp RG, Vittinghoff E, Aujesky D, Rodondi N: Subclinical thyroid dysfunction and the risk of heart failure events: an individual participant data analysis from 6 prospective cohorts. Circulation 2012; 126:1040-1049.
21 Pearce SH, Brabant G, Duntas LH, Monzani F, Peeters RP, Razvi S, Wemeau JL: 2013 ETA guideline: management of subclinical hypothyroidism. Eur Thyroid J 2013;2:215-228.

22 Hollowell JG, Staehling NW, Flanders WD, Hannon WH, Gunter EW, Spencer CA, Braverman LE: Serum TSH, $\mathrm{T}_{4}$, and thyroid antibodies in the United States population (1988 to 1994): National Health and Nutrition Examination Survey (NHANES III). J Clin Endocrinol Metab 2002;87:489-499.

23 Surks MI, Ortiz E, Daniels GH, Sawin CT, Col NF, Cobin RH, Franklyn JA, Hershman JM, Burman KD, Denke MA, Gorman C, Cooper RS, Weissman NJ: Subclinical thyroid disease: scientific review and guidelines for diagnosis and management. JAMA 2004;291:228-238.

24 Meyerovitch J, Rotman-Pikielny P, Sherf M, Battat E, Levy Y, Surks MI: Serum thyrotropin measurements in the community: five-year follow-up in a large network of primary care physicians. Arch Intern Med 2007;167:15331538.

25 Diez JJ, Iglesias P, Burman KD: Spontaneous normalization of thyrotropin concentrations in patients with subclinical hypothyroidism. J Clin Endocrinol Metab 2005;90:4124-4127.

26 Parle JV, Franklyn JA, Cross KW, Jones SC, Sheppard MC: Prevalence and follow-up of abnormal thyrotrophin (TSH) concentrations in the elderly in the United Kingdom. Clin Endocrinol 1991;34:77-83.

27 Virgini V, Wijsman L, Rodondi N, Bauer D, Kearney P, Gussekloo J, den Elzen W, Jukema W, Westendorp R, Ford I, Stott D, Mooijaart S: Subclinical thyroid dysfunction and functional capacity among elderly. Thyroid 2013; 24:208-214.

28 Yesavage JA, Brink TL, Rose TL, Lum O, Huang V, Adey M, Leirer VO: Development and validation of a geriatric depression screening scale: a preliminary report. J Psychiatr Res 1982;17:37-49.

29 D’Ath P, Katona P, Mullan E, Evans S, Katona C: Screening, detection and management of depression in elderly primary care attenders. I. The acceptability and performance of the 15-item Geriatric Depression Scale (GDS15) and the development of short versions. Fam Pract 1994;11:260-266.

30 de Craen AJ, Heeren TJ, Gussekloo J: Accuracy of the 15-item Geriatric Depression Scale (GDS-15) in a community sample of the oldest old. Int J Geriatr Psychiatry 2003;18:6366.

31 Dennis M, Kadri A, Coffey J: Depression in older people in the general hospital: a systematic review of screening instruments. Age Ageing 2012;41:148-154. 
32 Vinkers DJ, Gussekloo J, Stek ML, Westendorp RG, Van Der Mast RC: The 15-item Geriatric Depression Scale (GDS-15) detects changes in depressive symptoms after a major negative life event. The Leiden 85-plus Study. Int J Geriatr Psychiatry 2004;19:80-84.

33 de Waal MW, van der Weele GM, van der Mast RC, Assendelft WJ, Gussekloo J: The influence of the administration method on scores of the 15-item Geriatric Depression Scale in old age. Psychiatry Res 2012;197:280284.

34 Oomen HA, Schipperijn AJ, Drexhage HA: The prevalence of affective disorder and in particular of a rapid cycling of bipolar disorder in patients with abnormal thyroid function tests. Clin Endocrinol 1996;45:215-223.

35 Gulseren S, Gulseren L, Hekimsoy Z, Cetinay P, Ozen C, Tokatlioglu B: Depression, anxiety, health-related quality of life, and disability in patients with overt and subclinical thyroid dysfunction. Arch Med Res 2006;37:133139.
36 Samuels MH, Schuff KG, Carlson NE, Carello P, Janowsky JS: Health status, mood, and cognition in experimentally induced subclinical thyrotoxicosis. J Clin Endocrinol Metab 2008; 93:1730-1736.

37 Larisch R, Kley K, Nikolaus S, Sitte W, Franz M, Hautzel H, Tress W, Müller HW: Depression and anxiety in different thyroid function states. Horm Metab Res 2004;36:650-653.

38 de Jongh RT, Lips P, van Schoor NM, Rijs KJ, Deeg DJ, Comijs HC, Kramer MH, Vandenbroucke JP, Dekkers OM: Endogenous subclinical thyroid disorders, physical and cognitive function, depression, and mortality in older individuals. Eur J Endocrinol 2011;165: 545-554.

39 Engum A, Bjøro T, Mykletun A, Dahl AA: An association between depression, anxiety and thyroid function - a clinical fact or an artefact? Acta Psychiatr Scand 2002;106:27-34.

40 Vreeburg SA, Hoogendijk WJ, van Pelt J, Derijk RH, Verhagen JC, van Dyck R, Smit JH, Zitman FG, Penninx BW: Major depressive disorder and hypothalamic-pituitary-adrenal axis activity: results from a large cohort study. Arch Gen Psychiatry 2009;66:617-626.

41 Roberts LM, Pattison H, Roalfe A, Franklyn J, Wilson S, Hobbs FD, Parle JV: Is subclinical thyroid dysfunction in the elderly associated with depression or cognitive dysfunction? Ann Intern Med 2006;145:573-581.
42 Kong WM, Sheikh MH, Lumb PJ, Naoumova RP, Freedman DB, Crook M, Dore CJ, Finer $\mathrm{N}$ : A 6-month randomized trial of thyroxine treatment in women with mild subclinical hypothyroidism. Am J Med 2002;112:348-354.

43 Blum MR, Bauer DC, Collet TH, et al: Subclinical thyroid dysfunction and fracture risk: a meta-analysis. JAMA 2015;313:2055-2065.

44 Cappola AR, Fried LP, Arnold AM, Danese MD, Kuller LH, Burke GL, Tracy RP, Ladenson PW: Thyroid status, cardiovascular risk, and mortality in older adults. JAMA 2006; 295:1033-1041.

45 Svare A, Nilsen TI, Asvold BO, Forsmo S, Schei B, Bjøro T, Langhammer A: Does thyroid function influence fracture risk? Prospective data from the HUNT2 study, Norway. Eur J Endocrinol 2013;169:845-852.

46 Waring AC, Harrison S, Fink HA, Samuels MH, Cawthon PM, Zmuda JM, Orwoll ES, Bauer DC: A prospective study of thyroid function, bone loss, and fractures in older men: the MrOS study. J Bone Miner Res 2013; 28:472-479. 